\title{
The Effects of Inservice Education on Teachers' Knowledge of Junior Secondary School Social Studies Curriculum and Instruction in Delta State, Nigeria
}

\author{
Dr. (Mrs.) E.O. Okobia \\ Department of Educational Psychology and Curriculum Studies Faculty of Education, University of Benin, \\ Benin City Edo State, Nigeria
}

\begin{abstract}
The provision of competent professionally trained social studies teachers in adequate numbers has been a major challenge in the successful implementation of the social studies curriculum in junior secondary schools in Nigeria. In-service training of social studies teachers while still on the job has been identified as a functional strategy to enhance the professional competence of these teachers. This study was designed to evaluate the impact of in-service education on the knowledge of teachers on objectives, contents and teaching strategies employed in social studies. Sixty NCE social studies teachers and 60 teachers who obtained B.Ed in social studies through in-service training were recruited for the study using multi-stage random sampling from 30 junior secondary schools in Ika North East and Ika South Local Government Areas of Delta State of Nigeria. A questionnaire-based survey strategy was employed to test the social studies teachers' knowledge on objectives, contents and teaching strategies. The reliability coefficient of the instrument was found to be 0.81 using Cronbach Alpha technique. Data was analyzed using t-test for independent samples. The results showed that B.Ed teachers have significantly higher knowledge on objectives and content of the social studies curriculum but there was no significant difference in the knowledge of NCE and B.Ed teachers on instructional strategies. It was recommended that in-service education programs in social studies should focus not only on enhancing teachers' knowledge on objectives and content but also emphasis should be laid on knowledge of different teaching strategies for the teaching/learning of social studies.
\end{abstract}

Keywords: Inservice education, teachers' knowledge, Junior secondary school, social studies curriculum and instruction

\section{Introduction}

The importance of teachers and the role they play in the educative process are central to basic education. Successful educational improvement is intrinsically linked to professional development. One of the most persistent problems facing Nigerian education is that of improving the quality of teachers so as to produce well qualified, conscientious highly motivated, imaginative and committed teachers who would cope with the demands of the nation's educational system. The new millennium is filled with dramatic global transformation in technology, education, information, economy and social activities which pose immense challenges to the social studies teachers. Teachers of social studies need articulate professional orientation on how social studies could be appropriately taught if the goals of social studies must be realized to justify its introduction in the school curricula.

The subject matter is rich in cognitive and affective learning. It can provide the types of experiences necessary for raising a generation of disciplined, well adjusted, responsible and useful members of the Nigerian society. But the extent, to which the subject succeeds in achieving this purpose, is largely determined by the degree to which the subject is properly taught. Proper teaching of the subject according to Mkpa (1989) depends on the degree to which the teachers possess the competences needed for the task. It was unfortunate that at inception of social studies into the school system, there were no trained teachers to handle the subject. However by 1990 when social studies was established into the colleges of education, many candidates opted for social studies either as single major or double major. In Nigeria today there are over 60 colleges of education offering social studies and producing NCE teachers. Over the years, there is a growing concern about the quality of teacher training especially in the Colleges of Education. Teacher training institutions have been critiqued for inability to produce teachers who are properly grounded in pedagogy and content as well as ability to collaborate professionally in the work environment.

Lewin and Stuart (2003) in analyzing teacher preparatory programmes observed that subject content takes up to 80 percent of the teacher preparatory time. In this case, student teachers' learning may be heavily centred on role learning leaving them with insufficient understanding of the conceptual underpinnings or practice of new paradigms of teaching and learning. This scenario has adverse consequences on teachers' competency skills in classroom pedagogy. Although the initial teacher preparation is a component of the overall 
teacher effectiveness package, prospective teachers should while in training, be made to internalize the fact that their initial teacher preparation exposure would be complemented with continuing further education or inservice if effective teaching is to take place. Research in education has revealed that it is only through inservice training for teachers that the gulf between advancing knowledge and practice can be bridged. Inservice training is designed to add on the knowledge and skills already possessed by a serving teacher (Ikediegwu, 2001; Okojie, 2009). The most popular in-service programme in Nigeria is the one being organized by most universities where teachers have opportunity to attend during their vocation. This programme is popularly known as sandwich programme. It is a five years programme. But the beauty of it is that, the programme is arranged when schools are on holidays.

\section{Statement of Problem}

Learning to teach is a life-long pursuit and a teacher's education is a continuing education otherwise his ideas and methods became obsolete. Social studies is constantly undergoing review in order to keep abreast of the needs and demands of the society. Similarly, the social studies teachers need to be abreast with current research reports on the various aspects of social studies curriculum. Teachers have complex role and have more demands on them. Therefore they need new knowledge, skills and attitudes. It is also the belief of many educators that preservice training of teachers is not sufficient to prepare teachers for life. It was been argued that only through the growth of inservice education that the gulf between advancing knowledge and practice can be bridged. It was on the basis of this that the National Policy on Education (2004) emphasized that in-service training shall be developed as an integral part of continuing teacher education and shall also take care of all inadequacies. The acceptance of such responsibility by the government is a right step to ensure effectiveness and quality teaching and learning.

Quality education depends on the quality of the teachers. Inservice education ensures that teachers are kept up to date and adequately empowered to offer quality delivery. The pre-service training, might not perfectly prepare them for effective job performance. Therefore many reasonable teachers sought the opportunity of inservice education as a means of further professional development. In Nigeria, the major inservice education for secondary school teachers is the sandwich program offered by the faculties of education in Nigerian universities. Social studies is one of the disciplines in the inservice program. One would expect that this in-service program should influence the knowledge of the recipients about the junior secondary school social studies curriculum and instruction. It is on the basis of this, that this study attempts to assess the effects of in-service education on the knowledge of teachers on junior secondary school social studies curriculum and instruction. This study aims to achieve these objectives through the following research hypotheses.

\section{Research Hypotheses}

1. The knowledge of general objectives by B.Ed. teachers who have been exposed to inservice education will not be significantly different from the NCE teachers who are not yet exposed to inservice training.

2. To knowledge of content of social studies by B.Ed. teachers who have been exposed to inservice education will not be significantly different from the NCE teachers who are not yet exposed to inservice training.

3. The knowledge of instructional strategies by B.Ed. teachers who have been exposed to inservice education will not be significantly different from the NCE teachers who are not yet exposed to inservice training.

\section{Methodology}

This study was designed to evaluate the effect of inservice education on social studies teachers' knowledge of the general objectives, content and teaching strategies in social studies. Two groups of social studies teachers comprising 60 social studies teachers who possess NCE certificate in social studies and 60 teachers who have obtained B.Ed. social studies through inservice education were recruited for this study. The teachers were selected by multi-stage random sampling from thirty junior secondary schools in two local government areas (Ika South and Ika North East) of Delta State, Nigeria.

This study employed a self-administered questionnaire-based survey strategy designed to assess teachers' knowledge in the three areas of concern in this study including general objectives, content and instructional strategies. Ten items were developed for each of the three areas to give a total of 30 items. The questionnaire was of likert with two options: Agree and Disagree. A set of the questionnaire was administered to social studies experts for validation. The division of the instrument into three sections with equal number of items strengthened the content validity. To determine the reliability, the instrument was pretested and the reliability of the instrument was estimated using Cronbach Alpha. The reliability co-efficient was found to be 0.84 . The questionnaire was administered by the investigator and a team of two trained research assistants. All the 120 teachers sampled completed the questionnaires and the questionnaires were returned on the same day. 


\section{Data Analysis}

The instrument was administered to the teachers. The respondent marked the positively worded item "Agree" or the negatively worded item "Disagree". Responses were marked and scores collated.A total score obtained by each respondent for each of the three sections was recorded. Thus three scores were obtained for each of the respondent. The mean of the scores in each section for the group of $60 \mathrm{~B}$.Ed teachers and $60 \mathrm{NCE}$ teachers were obtained with their standard deviation. The t-test statistics was employed to test the significant difference in the knowledge of B.Ed. teachers and NCE teachers on the three different areas of social studies instruction. The hypotheses were tested at 0.05 level of significance.

\section{Results}

\section{Testing Hypotheses}

$\mathrm{Ho}_{1}$ : The knowledge of general objectives of social studies by B.Ed. teachers who have been exposed to inservice education will not be significantly different from the NCE teachers who are not yet exposed to inservice training.

\section{Data analyzed, presented on Table 1.}

Table 1: Test of significant difference in respect of knowledge of objectives of teaching social studies

\begin{tabular}{|l|l|l|l|l|l|l|}
\hline Group & N & Mean & Sd & df & T & Sig \\
\cline { 1 - 4 } NCE. Teachers & 60 & 7.38 & 2.01 & & \multirow{2}{*}{-2.54} & .012 \\
\hline B.Ed. teachers & 60 & 8.25 & 1.70 & 118 & -2 \\
\hline
\end{tabular}
$\alpha=.05$

The mean scores of NCE teachers on knowledge of objectives was 7.38 (sd 2.01) while the mean scores of B.Ed. teachers was 8.25 (sd -1.70). To test if the different is significant, the means scores of these teachers on knowledge of objectives of social studies were computed using the t-test. There was significant difference between the mean score of NCE and B.Ed. teachers $(t=-2.54, p=.012)$ testing at an alpha level of $0.05, \mathrm{p}<0.05$. Hypothesis is rejected. This means that inservice education had effect on B.Ed teachers' knowledge of the objectives of social studies.

$\mathrm{Ho}_{2}$ : The knowledge of content of social studies by B.Ed teachers who have been exposed to inservice education will not be significantly different from the NCE teachers who are not yet exposed to inservice training. Data analyzed presented on Table 2.

Table 2: Test of Significant difference in respect of knowledge of content of social studies

\begin{tabular}{|l|l|l|l|l|l|l|}
\hline Group & N & Mean & Sd & df & T & Sig \\
\hline NCE teachers & 60 & 6.51 & 1.56 & & & \\
\hline B.Ed. teachers & 60 & 7.25 & 1.46 & 118 & -2.664 & .009 \\
\hline
\end{tabular}

$\alpha=.05$

To test for significant difference between the mean scores of NCE teachers and B.Ed. teachers on knowledge of content of social studies. $\mathrm{t}=-2.664, \mathrm{p}=.009$. Testing at an alpha level of $0.05, \mathrm{p}<0.05$, hypothesis is rejected. There was significant difference between B.Ed teachers who have been exposed to inservice education and NCE teachers who are not yet exposed to inservice training. Inservice had effect on B.Ed. teachers' knowledge of content of social studies.

$\mathrm{Ho}_{3}$ : The knowledge of teaching strategies used in social studies by B.Ed. teachers who have been exposed to inservice education will not be significantly different from the NCE teachers who are not yet exposed to inservice training. Data analyzed, presented in Table 3.

Table 3: Test of Significant different in respect of Knowledge of Teaching Strategies used in Social Studies

\begin{tabular}{|l|l|l|l|l|l|l|}
\hline Group & N & Mean & Sd & df & T & Sig \\
\cline { 1 - 5 } NCE teachers & 60 & 5.90 & 1.71 & \multirow{2}{*}{118} & \multirow{2}{*}{1.63} \\
\hline B.Ed. teachers & 60 & 6.38 & 1.77 & & .107 \\
\hline
\end{tabular}
$\alpha=.05$

To test for significant difference between the mean scores of NCE teachers and B.Ed teachers on the knowledge of teaching strategies used in social studies, $t=1.63, p=.107$ testing at an alpha level of $0.05, p>$ 0.05 showing that there was no significant different. Hypothesis is retained. That means inservice education had no effect on B.Ed teachers'knowledge of teaching strategies. 


\section{Discussion}

The issue of lifelong professional development of teachers has been a subject of intense discourse among educationists in contemporary times. Several terms including inservice education, INSET, staff development and professional development have been used to describe the training and support that occur after teachers have received some initial preparation for the job. While the term 'inservice' often conjures up the narrow definition of short training sessions provided away from the school setting or programs to gain further teaching credentials, 'professional and staff development' connote more the idea of comprehensive development which may include training, ongoing support, career growth and incentives (Craig, Kratt \& Plessis, 1998).

Inservice programs are varied in nature and quality and only some have undergone formal evaluations to determine effectiveness of different organizational deliveries and the effect on students' achievement. The results of this study showed that inservice training had significant impact on socials studies teachers' knowledge of general objectives and content of social studies. The study revealed that B.Ed teachers who were exposed to inservice training performed better than the NCE teachers who are yet to be exposed to inservice training. The findings showed that the teachers who have been exposed to inservice education had better knowledge of the general objectives of social studies. Through inservice education teachers are able to update their knowledge in the subject. The study also revealed that the B.Ed. teachers had better knowledge of content of social studies.

This findings corroborate the reports of other investigators from both developing and developed regions of the world. In a comprehensive study on Nigerian teachers' perception of the curricula objectives of social studies, Mansaray and Ogunyemi (1994) revealed that most social studies teachers were unable to discriminate the objectives of social studies. It was obvious from their study that the teachers lacked adequate knowledge of the objectives of social studies teaching. Similarly this study provided evidence of the benefits of inservice education in equipping teachers with social studies philosophy, assumptions and the objectives of the subject. A more poignant revelation regarding the need for inservice training for NCE teachers came from the observations of Gwany (2005) in Northern Nigeria. After a critical review of the NCE programs in Colleges of Education in the region, he noted that the NCE training programs in Northern Nigeria were grossly inadequate.

According to him, the pedagogical content of the NCE programs are just sufficient to pass the senior secondary school certificate. This indicates that the training programs provided in the Colleges of Education in the region are not suitable for producing the caliber of professionally trained teachers required for implementing the junior secondary school social studies program. Similarly, Ali (1992) emphasized the need for teachers to keep abreast in their field of study in order to be able to communicate their knowledge effectively. This can only happen when teachers are professionally trained through in-service program. As noted by Okojie (2009), inservice training fills gaps and equips teachers with skills and update their content knowledge.

Similar promising views of the benefits of inservice training have been replicated in several other countries of the world including Borg (2011) in the United Kingdom; Coruhlu and Cepni (2010). In a qualitative longitudinal study in the United Kingdom, Borg (2009) examined the impact of an intensive inservice teacher education program on beliefs of six English Language teachers. The results revealed that the program had considerable impact on the teachers' beliefs. The course allowed the teachers to think more explicitly about, became aware of, and articulate their beliefs. Coruhlu and Cepni (2010) investigated the effects of inservice training course related to alternative measurement and assessment technique on teachers' pedagogical content knowledge and attitudes towards inservice education (INSET). The results of their study revealed that inservice training course program had a meaningful effect on improving science and technology teachers' pedagodical content knowledge. Similarly, Gumbo, Makgoto and Muller evaluated the effect of ACE technology training program on technology teachers' professional development. The findings revealed that the teachers overwhelmingly benefited from the training in terms of their understanding of technology.

The findings of this research revealed that the inservice training had no significant impact on teachers' knowledge of teaching strategies; there was no significant difference in knowledge of teaching strategies between B.Ed teachers who have been exposed to in-service education and NCE teachers who are not yet exposed to in-service education. This findings are in keeping with the report of Iyamu and Otote (2006) who in their assessment of inquiry teaching competencies of professionally trained graduate and non-graduate social studies teachers in Junior Secondary Schools in South Central Nigeria found that professionally trained nongraduate (NCE) teachers demonstrated more competence compared to the graduate (B.Ed) teachers. They noted that this finding reflects the quality of teacher education at the two levels. This findings also corroborate the views of Melford (1999) and Ajala (2000) that teacher education programs in Nigerian Universities seem to be weak and inadequate. As they noted, teaching practice is poorly organized and supervised in the University Faculties of Education and students are not adequately exposed through microteaching. These weaknesses in exposure to instructional strategies in the University teacher education programs have been attributed largely to shortage of teaching-learning facilities, poorly motivated lecturers and over-population of students.

The findings of this study are also in keeping with the observations of Wolff et al. (1994) who noted that research on inservice training shows generally inadequate results, particularly when these programs are 
designed to provide teachers with another degree. Effective professional development programs that are known to make a difference to the quality of teaching support teachers to develop their classroom practice. Programs that provide further credentials are important for developing professional status of teachers, establishing teaching standards and assisting in career growth. However, these training programs do not provide adequate linkages and ongoing support with classroom practice and therefore actual instructional practices are often not changed and the quality of teaching and student learning is hindered. All other recent studies in Nigeria that have evaluated instructional delivery in social studies have reported disappointing results. The reports of Oganwu (2004), Mezieobi (2004), Olufu, Agbo and Ogodo (2005), Okobia (2009) all indicated that social studies teaching in Nigerian junior secondary school depended largely on teacher-centered, didactic and expository instructional methods to the neglect of the recommended students-centered techniques. Deficiencies in instructional strategies by teachers have also been re-echoed by Ben-Clays (1999) and Lewin and Stuart (2003). According to Ben-Clays (1999), these deficiencies are reflections of the type and quality of training received by teachers, for teachers tend to teach the ways they were taught. Similarly, Lewin and Stuart (2003) in analyzing teacher preparatory programs, observed that subject content takes up to 80 percent of the teacher preparation time. In this case, student teachers' learning may be heavily centred on rote learning, leaving them with insufficient practice of new paradigms of teaching and learning. Another reason which could be responsible for this disappointing result is that most teacher educators teaching social studies in teacher education program especially in the universities are not themselves trained in social studies education.

Research in teacher education, curriculum development and implementation and related fields have highlighted the essential characteristics of effective professional and staff development programs (Craig, Kratt \& du Plessis, 1998). These include: (1) Needs Assessment, (2) Careful Planning in the Wider Context, (3) Participatory Planning and Implementation, (4) Applicable Curriculum Content and Methods and (5) Ongoing Guidance, Monitoring and Support. In most developing countries such as Nigeria, volumes of comprehensive documents exist in Federal and State Ministries of Education, Local Government Education Boards, and Teacher Education Institutions in the areas of Needs Assessment and Curriculum Content and Methods.

However, there are major weaknesses in the areas of Participatory Planning and Implementation and Ongoing Guidance, Monitoring and Support. Often the teachers at the local level are not involved in the curriculum development processes. New curriculum and changes in existing curricula are merely passed down to the teachers who have very limited knowledge on the curriculum content. In addition, even when the teachers are exposed to new knowledge through inservice and other staff development programs, very little exists in the areas of Ongoing Guidance, Monitoring and Support when the teachers return to their localities. As a result, the whole essence of the staff development programs is not achieved and the teachers resort to their traditional ways of doing things in the classroom.

Esu (1991) states that in the work of Lawrence (1974), reviews and analyzes of ninety-seven studies on inservice education, those programs that involved participant teachers in the planning of such activities tended to have greater success in accomplishing their objectives than those without the assistance of the participants. Tatto (1997) concludes from her review of the work of Mosenthal and Ball (1992), National Center for Research on Teacher Learning (1991), Schiefelbein (1992), and Tatto et al. (1993) that the most effective and relevant inservice programs are those that allow high levels of participation in both the design and implementation. Examples of successful teacher programs that include high level of teacher and community participation include the Compensatory Education Project in Malaysia (Dove, 1982), the Nigerian Primary Education Improvement Project (Dove, 1982), the Escuela Nueva in Colombia (Tatto, 1995), the NEU in Guatemala, and the Compensatory Program to Address Educational Lag, or PARE in Mexico (Tatto, 1995).

The failure of inservice and other professional development programs particularly in Nigeria and other developing countries stem largely from failure to provide ongoing guidance, monitoring and support. Programs that focus on continuous development to guide, monitor and support necessary skills, knowledge and new ideas tend to be more successful in bringing about change at the classroom level than those that seek quick fixes to fill up deficiencies or those that simply provide a qualification. Tatto (1997) reports that inservice programs typically focus on helping teachers implement new curricula in conjunction with state values and educational reforms (Ajie, 1981; Grieg, 1989; Konting, 1993; Maoldinomhnaigh, 1987; Van de Sijde and Tomic, 1982; Van Tulder and Veenman 1991). This ongoing support is essential for effective transfer of skills and is easiest developed through the school-based model (Craig, Kraft and du Plessis, 1998). The main support comes both from within the school environment (e.g., principal, other teachers) and personnel from the larger educational system and community. At the teacher level, support to help the application of new skills into the classroom includes: (1) coaching about classroom skills and management from mentors and peers; (2) a continuing study group with other teachers with similar inservice experiences; (3) coordination of the inservice with regular supervision of teachers; and (4) provision made for traveling consultants to visit teachers.

Several organizational models for professional development of teachers have been described. Craig, Kratt and Plessis (1998) provides an excellent and detailed discourse of the different organizational models 
including: (1) the Continuous or Lifelong Professional Development Model, (2) the School-Based Model, (3) School Clusters, Local Teacher's Centers and Resource Centers, (4) College or Centralized Institution Model, e.g. Teacher College, University, (5) Partnerships, (6) Distance Education Model and (7) Alternative Needs Response Models. Each of these models has its strengths and weaknesses and serves the needs of different communities/countries based on their peculiar needs and circumstances. The dominant form of teacher professional development in Nigeria is the College or Centralized Institution Model which requires participants to spend most of their time away from the school setting. This model: (1) is used more for residential vacation programs; (2) is planned and formal; (3) is used more for gaining further teaching and administrative credentials; and (4) should be combined with continuous practice in the classroom and integration of knowledge and skills learned with classroom realities. As noted by Craig, Kratt and du Plessis (1998), this practice and integration is weak.

\section{Conclusion}

The teacher plays pivotal role in the educational program and teaching is not complete until knowledge has been successfully impacted to the learners. The findings of this study revealed that in-service education had positive impact on teachers' knowledge of objectives and content of social studies. However, inservice education had no significant effect on teachers' knowledge of teaching strategies used in social studies teaching.

This scenario may have adverse consequences on their competency in classroom pedagogy. Therefore social studies teachers need to upgrade their knowledge and skills through more intensive in-service programs.

The teacher education programs involved in in-service training of teachers must evolve a higher level of responsibility. Concrete efforts must be made to ensure that the inservice education programs provide adequate linkages and ongoing support with actual classroom instructional practices.

\section{Recommendations}

Life long professional development of teachers is a sine-qua-non for the success of any teaching/learning experience. This premise is particularly relevant in the rapidly evolving and ever changing field of social studies. The burst of technological change and emerging globalization in the past few decades have necessitated the continuous evaluation and re-evaluation of the curriculum content of social studies. Many new content areas such as population education, environmental education, family life education, sexuality education, peace education, civic education, etc have been added to the curriculum content of social studies in the past few years. In addition, the emergence of new information and communication technologies (ICT) and the radical impact of ICT on teachers and teaching has been re-echoed by The 1998 UNESCO World Education Report titled "Teachers and Teaching in a Changing World". These are interesting and revolutionary times in the teaching and learning of social studies. The socials studies teachers themselves and teacher education programs must keep pace with these changes and emerging challenges by evolving sound and deep rooted life long professional and staff development programs if the lofty objectives of the socials studies curriculum are to be realized.

In suggesting ways to strengthen the current inservice training programs for social studies teachers in Nigeria, it is important to take cognizance of the key essential elements for professional development programs as catalogued by Craig, Kratt and du Plessis (1998). These essential elements would be that the programs: (1) focus on concrete and specific training for instructional and management practice; (2) are appropriate to the needs of the teacher; (3) involve teacher and other staff in the planning and implementation of both short and long-term activities; (3) include a balance of theory and practice; (4) include small-group workshops, peer observations and feedback, coaching and demonstrations; (5) ensure implementation in the classroom of the acquired learning; (6) provide continuous guidance and support (head teacher, peers, and other staff); (7) have the support and participation and other school leaders; (8) enable participation through release time; (9) provide regular meetings for problem solving; (10) fit within the context of the local community and school culture; and (11) fit within the broad, long-term professional development and school improvement program.

It is obvious from the above highlights that the current dominant College or Centralized Institutionbased model of inservice teacher education program in Nigeria suffers serious setback particularly in the areas of social studies teachers' involvement in Participatory Planning and Implementation and Ongoing Guidance, Monitoring and Support. There is urgent need for a complete overhaul of the current teacher professional and staff development programs in social studies. In addition to the current Centralized Institution-based model, other professional and staff development models that have shown promising results such as the Continuous or Lifelong Professional Development Model, the School-Based Model and the School Clusters, Local Teacher's Centers and Resource Centers should be integrated into the current social studies teachers' professional development programs. Social studies teachers should be integrated and made to play active role in the initial planning and implementation of these programs. It is also important to emphasize the need for ongoing guidance, monitoring and support when these teachers return to the classroom. The schools themselves have a 
tremendous role to play in this regard. Educational supervising agencies including the Ministries of Education at the Federal and State levels, Local Government Education Boards and Teacher Education Institutions should provide the necessary support to ensure adequate and ongoing supervision and evaluation of the activities of social studies teachers in the classroom. Adequate and relevant instructional materials including information and communication technology (ICT) tools that help the teacher and pupils in the teaching/learning process should be provided to enhance teaching and learning in the social studies classroom.

\section{References}

[1]. Ajala, A.O. (2000) Problems of teacher education in Nigeria: Lagos: Talatan.

[2]. Ajie, V.E.N. (1981) A critical study of inservice teacher education for primary school teachers in Rivers State, Nigeria. Nairobi, Kenya: African Curriculum Organization; Germany: Agency for Technical Cooperation; Kenyan Institute of Education; Nairobi University, African Studies in Curriculum Development and Evaluation, No. 18.

[3]. Ali, H. (1999). Professionalism in teacher education in Nigerian Universities: Issues and expectations. Oshodi, Ngieria Eudar Publishers.

[4]. Ben-Clays, M (1999) Assessing good teaching. Journal of Educational Studies 12 (1\&2):23-32.

[5]. Borg, S. (2011) The impact of inservice teacher education on language teachers' beliefs. Science Direct System 39 (2011). P 370 380. United Kingdom. http://iatefl.british.council.org/2012/sites.

[6]. Coruhlu, T.S., Cepni, S. (2010) Reflection of an inservice education course program: Pedagogical content knowledge about alternative measurement and assessment techniques and attitude development. Elementary Education Online, 9(3):1106-1121.

[7]. Craig, H.J., Kratt, R.J., du Plessis, J. (1998) Lessons learned from ongoing professional development - The years after initial preparation: In: Teacher development: Making an impact. USAID Advancing Basic Education and Literacy Project: World Bank Human Development Network: Effective Schools and Teachers. November, 1998. p 105-140.

[8]. Dove, L. (1982) The deployment and training of teachers for remote rural schools in less-developed countries. International Review of Education. Hamburg: UNESCO Institute for Education.

[9]. Esu, A. (1991) Inservice teacher education in Nigeria: A case study. Journal of Education for Teaching 17(2):189-199.

[10]. Federal Republic of Nigeria 2004. National Policy on Education. Lagos. NERDC.

[11]. Grieg, J.W. (1989) Distance education and educational reform in Jamaica: The clock is ticking. Report to the Ministry of Education of Jamaica prepared at the request of the Commonwealth of Learning. Vancouver, British Columbia: Commonwealth of Learning.

[12]. Gumbo, M., Makgoto, M., \& Muller, H. (2012) The impact of inservice technology programs on technology teachers. Journal of Technology Studies, 38(1): http://scholar.lib.vt.edu/ejournals/jots/v38nl/gumbo.html.

[13]. Gwany, D.M. (2005) Teaching professionalism in Nigeria. Paradoxes, Ironies Challenges and Prospects. Paper presented at the Maidan Faculty of Education Week 1 Commemoration of the $30^{\text {th }}$ Anniversary of the faculty of education, university of Maiduguri, $15^{\text {th }}$ July.

[14]. Ikediugwu, N. (2001) Inservice training: A strategy for improving teacher competence in Anambra State secondary schools. Nigerian journal of curriculum and instruction. Vol 10(1) 42-44.

[15]. Iyamu, E.O.S., Otote, C.O. (2006) Assessment of inquiry teaching competencies of social studies teachers in junior secondary schools in South Central Nigeria. http://www.itdl.org/Journal/Jul_06/article04.html.

[16]. Konting, M.M. (1993) In search of good practice: Learning from the effective teachers in Malaysia. Paper presented at the Annual Meeting of the British Educational Research Association, Liverpool, UK.

[17]. Lewin, K.M. and Stuart, J.S. (2003) Researching teacher education: New perspective on practice, performance and policy. Multi-site teacher education research project (MUSTER) synthesis report (London Department for International Development).

[18]. Mansaray, A and Ogunyemi, S.A. (1994.) Nigerian teachers' perception of the curricular objectives of social studies. studies in education. 1(1), 38-45.

[19]. Maoldomhnaigh, M.O. (1987) Teaching outcomes of short inservice courses in Experimental Science for primary teachers. Research in Science and Technological Education 5(1):37-42.

[20]. Melford, D. (1999) Teacher education in Nigeria. New York: Aston.

[21]. Mezieobi, K.A. (2004). Evaluation of the implementation of the junior secondary school social studies curriculum in Abia State. Unpublished Ph.D thesis Delta State University, Abraka, Nigeria.

[22]. Mkpa, M.A. (1989). Identification of preservice instructional competences for social studies teachers. Nigerian journal of social studies. A journal of Social Studies Association of Nigerian (SOSAN). 1(1): 70-74.

[23]. Mosenthal, J., \& Ball, D. (1992): Constructing new reforms of subject matter instruction: Subject matter knowledge in inservice teacher education. Journal of Teacher Education 43(5):347-356.

[24]. National Center for Research of Teacher Learning (1991) Findings from the teacher education and learning to teach study: Final report of the National Center for Research on Teacher Education. Special Report, National Center for Research on Teacher Learning. East Lansing: Michigan State University.

[25]. Oganwu, P.( 2004). The effectiveness of guide discussion, problem solving inquiry and expository lecture strategies on social studies concept attainment. Unpublished Ph.D thesis Delta State University.

[26]. Okobia, Esther O.( 2009) An assessment of the implementation of junior secondary school social studies curriculum in Edo State. Unpublished Ph.D thesis, University of Benin, Benin City, Nigeria.

[27]. Okojie, M.U.( 2009) Teacher education: challenges for the $21^{\text {st }}$ century. Multidisciplinary journal of research development. Vol. 13(1): $93-100$.

[28]. Olufu, M.A., Agbo, F.O., Ogodo, F.A. (2005) Assessing teacher's awareness and application of recommended instructional strate gies in the implementation of primary science curriculum. Journal of Curriculum Organization of Nigeria. 12(1):127-133.

[29]. Schiefelbein, E. (1992) Redefining basic education for Latin America: Lessons to be learned from the Colombia Escuela Nueva. Paris: IIEP.

[30]. Tatto, M.T. (1997) Limits and constraints to effective teacher education (Unpublished Manuscript).

[31]. Tatto, M.T. (1995) Reconstructing teacher education for a global community. Paper presented at the Third Oxford International Conference, New College, Oxford, England.

[32]. Tatto, M.T., and Kularatna, N.G. (1993) The interpersonal dimension of teacher education: Comparing distance education with two other programs in Sri Lanka. International Journal of Educational Research 19(8):755-778.

[33]. Van der Sijde, P.C., and Tomic, W. (1992) The influence of a teacher training program on student perception of classroom climate. Journal of Education for Teaching 18(3):287-295. 
[34]. Van Tulder, M. and Veenam (1991) Characteristics of effective inservice programs and activities: Results of a Dutch survey. Educational Studies 17(1):25-48.

[35]. Wolff, L, Schiefelbein, E., Valanzuela, J. (1994) Improving the quality of primary education in Latin America and the Caribbean: Toward the $21^{\text {st }}$ Century. Discussion Paper 257. Washington, D.C.: The World Bank. 